\title{
Comparison between diploid and tetraploid citrus rootstocks: morphological characterization and growth evaluation
}

\author{
Divanilde Guerra ( $\left.{ }^{1 *}\right)$; Maria Teresa Schifino Wittmann (2); Sergio Francisco Schwarz (1) \\ Paulo Vitor Dutra de Souza ( $\left.{ }^{1}\right)$; Mateus Pereira Gonzatto $\left({ }^{1}\right)$; Roberto Luis Weiler $\left({ }^{2}\right)$ \\ (') Universidade Federal do Rio Grande do Sul (UFRGS), Faculdade de Agronomia, Programa de Pós-graduação em Fitotecnia, \\ Departamento de Horticultura e Silvicultura, Av. Bento Gonçalves, 7712, 91501-970 Porto Alegre (RS), Brasil. \\ (2) Universidade Federal do Rio Grande do Sul (UFRGS), Programa de Pós-graduação em Zootecnia, \\ Departamento de Plantas Forrageiras e Agrometeorologia, 91501-970, Porto Alegre (RS), Brasil. \\ (*) Autora correspondente: divanildeguerra@yahoo.com.br
}

Received: Sept. 25, 2013; Accepted: Jan. 13, 2014

\begin{abstract}
Tetraploid citrus rootstocks may present different morphological characteristics and growth when compared to diploid ones. This worked aimed at comparing morphological characteristics and height growth of diploid and tetraploid plants from the rootstocks 'Swingle' citrumelo [C. paradise Macf. x Poncirus trifoliate (L.) Raf], citrange 'Troyer' (C. sinensis (L.) Osb. $x$ P. trifoliata) and citranges 'Fepagro C 13' and 'Fepagro C 37' [C. sinensis Cv. Pêra x P. trifoliata] during twelve months. Diploid (2n=18) and tetraploid $(2 n=36)$ plants originated from the same seed were identified, cultivated and evaluated every 45 days regarding color, height, petiole length, leaf length and central leaflet width. Significant differences were observed for the evaluated characteristics: the average of petiole length was $1.78 \mathrm{~cm}$ in the diploid and $0.99 \mathrm{~cm}$ in the tetraploid plants; the average of leaf length was $2.32 \mathrm{~cm}$ in the diploid and $2.95 \mathrm{~cm}$ in the tetraploid plants; the average of central leaflet width was $1.33 \mathrm{~cm}$ in the diploid and $1.69 \mathrm{~cm}$ in the tetraploid plants. Moreover, tetraploid plants had darker and thicker leaves than the diploid ones. Variation regarding height was observed and the diploid plants presented higher growth than the tetraploid ones. As tetraploid plants are smaller, have a slow height growth and wider and longer leaves.
\end{abstract}

Key words: Citrus, morphology, leaf color, height, dwarfing.

\section{Comparação entre porta-enxertos cítricos diploides e tetraploides: Caracterização morfológica e avaliação do crescimento}

\section{Resumo}

Porta-enxertos cítricos tetraploides podem apresentar características morfológicas e desenvolvimento diferenciados comparados a plantas diploides. Este trabalho teve como objetivo avaliar características morfológicas e o crescimento em altura de plantas diploides e tetraploides dos porta-enxertos citrumelo Swingle [C. paradisi Macf. x Poncirus trifoliata (L.) Raf], citrange Troyer [C. sinensis (L.) Osb. x P. trifoliata] e dos citranges Fepagro C 13 e Fepagro C 37 (C. sinensis Cv. Pêra x P. trifoliata) por um período de 12 meses. Plantas diploides $(2 n=18)$ e tetraploides $(2 n=36)$ oriundas da mesma semente foram identificadas, estabelecidas e avaliadas a cada 45 dias quanto a cor, altura, comprimento do pecíolo, da folha e largura do limbo do folíolo central. Diferenças significativas foram observadas nos caracteres avaliados: a média do comprimento do pecíolo nas plantas diploides foi de $1,78 \mathrm{~cm}$ e, nas tetraploides, de 0,99 cm; a média do comprimento das folhas nas diploides foi de 2,32cm e nas tetraploides de 2,95 cm; a média de largura dos folíolos centrais das folhas das plantas diploides foi de 1,33 cm e, nas tetraploides, de $1,69 \mathrm{~cm}$; além disso, as plantas tetraploides apresentaram folhas com coloração mais escura e mais espessas do que as das diploides. Variações foram observadas na altura, com as plantas diploides apresentando maior crescimento que as tetraploides. Portanto, plantas tetraploides apresentam menor tamanho, crescimento em altura mais lento e folhas mais largas e compridas.

Palavras-chave: Citrus, morfologia, cor da folha, altura, ananizante. 


\section{INTRODUCTION}

The rootstock is important in establishing a good quality orchard, since it influences several characteristics of the plant and fruit (Davies and Albrigo, 1994; Pompeu Junior, 2005; Schäfer and Dornelles, 2000), besides increasing tolerance to phytosanitary problems (Chagas et al., 2007).

In all citrus regions of the world, there is a strong tendency to use a small variety of rootstocks. In Brazil, for several decades, few varieties were used when creating orchards, jeopardizing production due to the numerous phytosanitary problems that affect the culture, exposing the productive sector to the outbreak of new diseases (Guerra et al., 2012; Moreira et al., 2010; Passos et al., 2006). To maintain the citrus production in Brazil and reduce the risk of orchards being decimated, it is essential the rational utilization of varieties, the use of rootstocks tolerant/resistance to plagues and diseases and well adapted to the distinct soil and environmental conditions (Moreira et al., 2010; Passos et al., 2006).

Most citrus species are diploid $(2 \mathrm{n}=2 \mathrm{x}=18)$, however polyploid plants, like triploid $(2 \mathrm{n}=3 \mathrm{x}=27)$ and tetraploid $(2 \mathrm{n}=4 \mathrm{x}=36)$, can be found in diploid populations (Aleza et al., 2011; Cameron and Frost, 1968; Hussain et al., 2012; Lee, 1988), being originated sexually through the fusion of nonreduced gametes or somatically, by chromosome duplication in nuclear cells and the non-division of these cells in two during mitoses (Cameron and Frost, 1968; Lee, 1988).

In citrus, tetraploid plants can be used as an alternative for the diversification of rootstocks, since they present a greater genetic variability due to the new possibilities of recombination, besides being able to be used as dwarf rootstocks (Cameron and Frost, 1968; Lee, 1988), since the new selections of rootstocks should confer productivity and quality to the fruit of the scion, be tolerant to the main plagues and diseases of the culture, and also induce plant size reduction (Gonzatto et al., 2011; Pompeu Junior and Blumer, 2009).

This study aimed at identifying polyploid plants obtained from diploid citrus rootstocks and describe the morphological characterization and growth analysis of height in diploid and tetraploid citrus plants.

\section{MATERIAL AND METHODS}

Fruits of the citrus rootstocks citrumelo 'Swingle' [ $C$. paradise Macf. $\mathrm{x}$ Poncirus trifoliata (L.)Raf] and citranges 'Troyer' (C. sinensis (L.) Osb. $\times$ P. trifoliata), 'Fepagro C 13' and 'Fepagro C 37' [C. sinensis cv. Pêra x P. trifoliata] were collected in a green-house in the year of 2009 in order to conduct the experiment.
In a laboratory, the fruits collected were washed and disinfected by being immersed in alcohol $70 \%$ for 10 minutes, and afterwards being immersed in a solution of sodium hypochlorite ( $2 \%$ of active ingredient) for five minutes and a triple wash with autoclaved deionized water. Afterwards, the fruits were opened and the seeds collected and disinfected following the methodology described above. In a sterile laminar flow chamber, the outer (testa) and inner (tegmen) teguments were removed and the seeds put to germinate in test tubes containing $30 \mathrm{~mL}$ of MS medium (Murashige and Skoog, 1962), which were kept in a controlled environment, with a photoperiod of 16 hours and a temperature of $25 \pm 2{ }^{\circ} \mathrm{C}$ until the plants reached $10 \mathrm{~cm}$ in height. In several species of citrus, polyembryony, is a common phenomenon. In the present study, when more than one seedling per seed occurred, these were identified with colored cotton swabs, with one color for each seed and transplanted to vases containing Rendmax ${ }^{\oplus}$ citrus substrate and acclimatized in a green-house. The plants were evaluated according to ploidy level using the technique of flow cytometry with the help of a Partec "Cy Flox Ploidy Analyser" cytometer, following the methodology described by Aleza et al. (2009).

Tetraploid and diploid plants were found in the same seed in the rootstocks of citrumelo 'Swingle', citrange 'Troyer' and citranges 'Fepagro C 13' and 'Fepagro C 37'. The ploidy level of these plants was confirmed by chromosome count in somatic cells of root tips according to the methodology described by Dahmer et al. (2013). After confirming the ploidy level, the plants were transplanted to bigger vases, with capacity of three liters, filled with the same citrus substrate and kept side by side in the green house. The irrigation was manual and the fertilization based on NPK fertigation.

Diplioid and tetraploid plants originated from the same seed were transplanted and evaluated regarding their height one day after transplantation (DAT), on 08/03/2010, and afterwards every 45 days, on $09 / 17 / 2010,11 / 01 / 2010$, 12/16/2010, 01/31/2011,03/17/2011,05/02/2011, $06 / 16 / 2011$ and $08 / 01 / 2011$. In total, each material was evaluated eight times. The morphological evaluation of the leaves consisted on measuring three leaves completely expanded from each plant and their respective leaflets, by measuring the length of the petiole, width (at the widest point of the leaf blade) and leaf length with the help of a pachymeterr. The analyses of these trifoliated rootstocks were conducted in the central leaflet, i.e., the largest one. The leaves were evaluated and classified according to the classes in table 1, according to type, color, petiole length compared to the blade, winged petiole, petiole and blade shape and shape of the edges according to the descriptors proposed by the International Board for Plant Genetic Resources (IBPGR, 1988). The plant growth in height was measured with the help of a graduated rule, beginning at the substrate surface until the highest growth point, on the dates mentioned above. 
The results obtained were analyzed statistically with the Tukey at the $1 \%$ significance test $(\mathrm{p}<0.01)$, using the statistical program SAS (SAS, 2000).

\section{RESULTS AND DISCUSSION}

In the flow cytometry analysis 406 plants from 83 seeds were evaluated, whereas four seeds, one of each rootstock of citrumelo 'Swingle', citrange 'Troyer' and citranges 'Fepagro C 13' and 'Fepagro C 37' produced a tetraploid and a diploid plant simultaneously in the same seed. The ploidy level of these plants was confirmed as tetraploid (Figure 1) by analyzing somatic cells from root ends. The presence of diploid and tetraploid plants in the same seed appears to be common in citrus and has already been described by Aleza et al. (2011).

In the morphological evaluations of the diploid and tetraploid plants according to the morphological descriptor of the IBPGR (1988) (Table 1) all the plants presented type 2 leaves, that is, trifoliate (Table 2 and Figure 2).

Trifoliate leaves have already been described in the morphological characterization of the citrumelo 'Swingle' and citrange 'Troyer' rootstocks, while the characterization

Table 1. Morphological descriptors of the leaves and their classes used in morphological characterization of the diploid and polyploid plants according to the IBPGR (1988)

\begin{tabular}{|cc|}
\hline Characteristic & Classes \\
Type & Simple, Trifoliate \\
Color & Light Green, Green, Dark Green \\
\hline Petiole Length X Blade & $\begin{array}{c}\text { Sessile, Short-petiolate, Longipetiolate } \\
\text { Petiole Winged }\end{array}$ \\
\hline Petiole Shape & Absent, Narrow, Large \\
\hline Blade Shape & Cordate, Deltoid, Obovate \\
\hline Shape of the edges & Crenade, Serrated, Full, Rolling \\
\hline
\end{tabular}
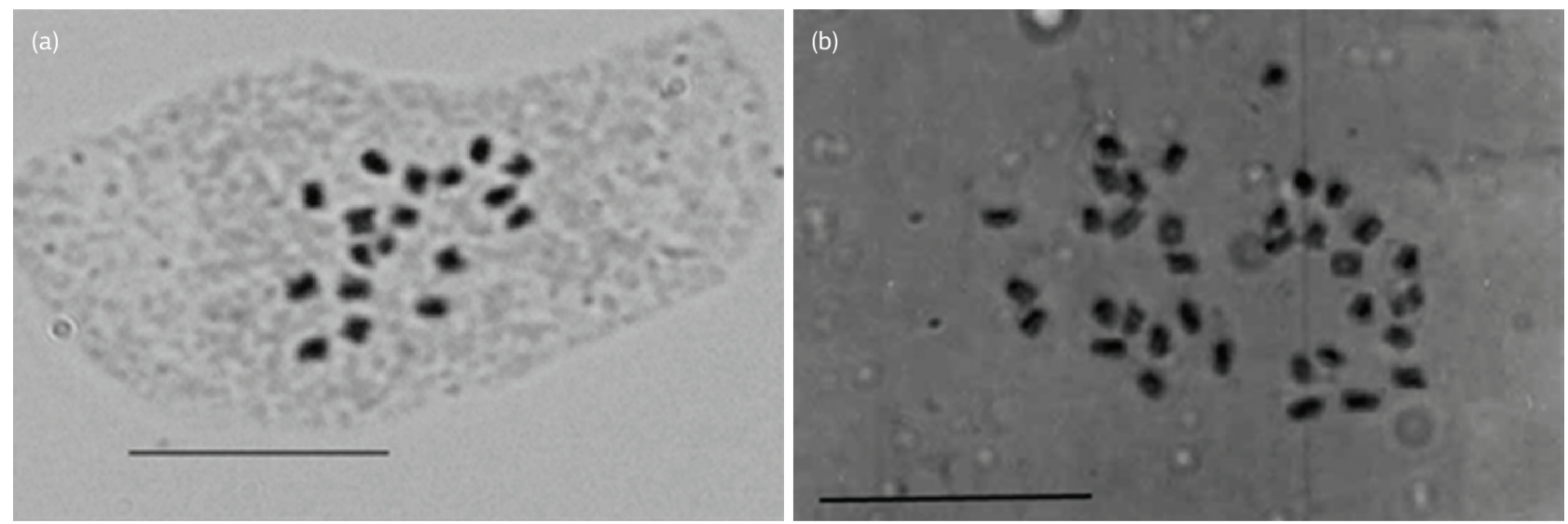

Figure 1. Determination the ploidy level by chromosome count in somatic cells of root tips of citrus rootstocks. (a) Diploid plant rootstock Citrange 'Fepagro C 13'; (b) Tetraploid plant rootstock Citrange 'Fepagro C 13'. Scale Bar = $10 \mu \mathrm{m}$. 
Table 2. Morphological characterization of leaves of the diploid and tetraploid plants of citrus rootstocks

\begin{tabular}{|c|c|c|c|c|c|c|c|c|}
\hline Rootstock & Ploidy & Type & Color & Petiole $\mathrm{x}$ Blade & Winged Petiole & Petiole Shape & Blade Shape & Edges Shape \\
\hline \multirow{2}{*}{ 'Swingle' } & $2 X$ & 2 & G & $\mathrm{SP}$ & Narrow & Obovate & Ellipsoid & Serrated \\
\hline & $4 X$ & 2 & DG & SP & Narrow & Obovate & Ellipsoid & Serrated \\
\hline \multirow{2}{*}{ 'Troyer' } & $2 x$ & 2 & G & SP & Narrow & Obovate & Ellipsoid & Serrated \\
\hline & $4 X$ & 2 & DG & SP & Narrow & Obovate & Ellipsoid & Serrated \\
\hline \multirow{2}{*}{$\begin{array}{c}\text { 'Fepagro } \\
\text { C 13' }\end{array}$} & $2 x$ & 2 & G & SP & Narrow & Obovate & Ellipsoid & Serrated \\
\hline & $4 X$ & 2 & DG & SP & Narrow & Obovate & Orbiculate & Serrated \\
\hline \multirow{2}{*}{$\begin{array}{c}\text { ‘Fepagro } \\
\text { C 37’ }\end{array}$} & $2 x$ & 2 & $G$ & SP & Narrow & Obovate & Ellipsoid & Serrated \\
\hline & $4 X$ & 2 & DG & SP & Narrow & Obovate & Ellipsoid & Serrated \\
\hline
\end{tabular}

Leaves type 2= Trifoliate; $\mathrm{G}=\mathrm{Green}$ coloring; $\mathrm{DG}=$ Darkgreen; $\mathrm{SP}=$ Short-petiolate

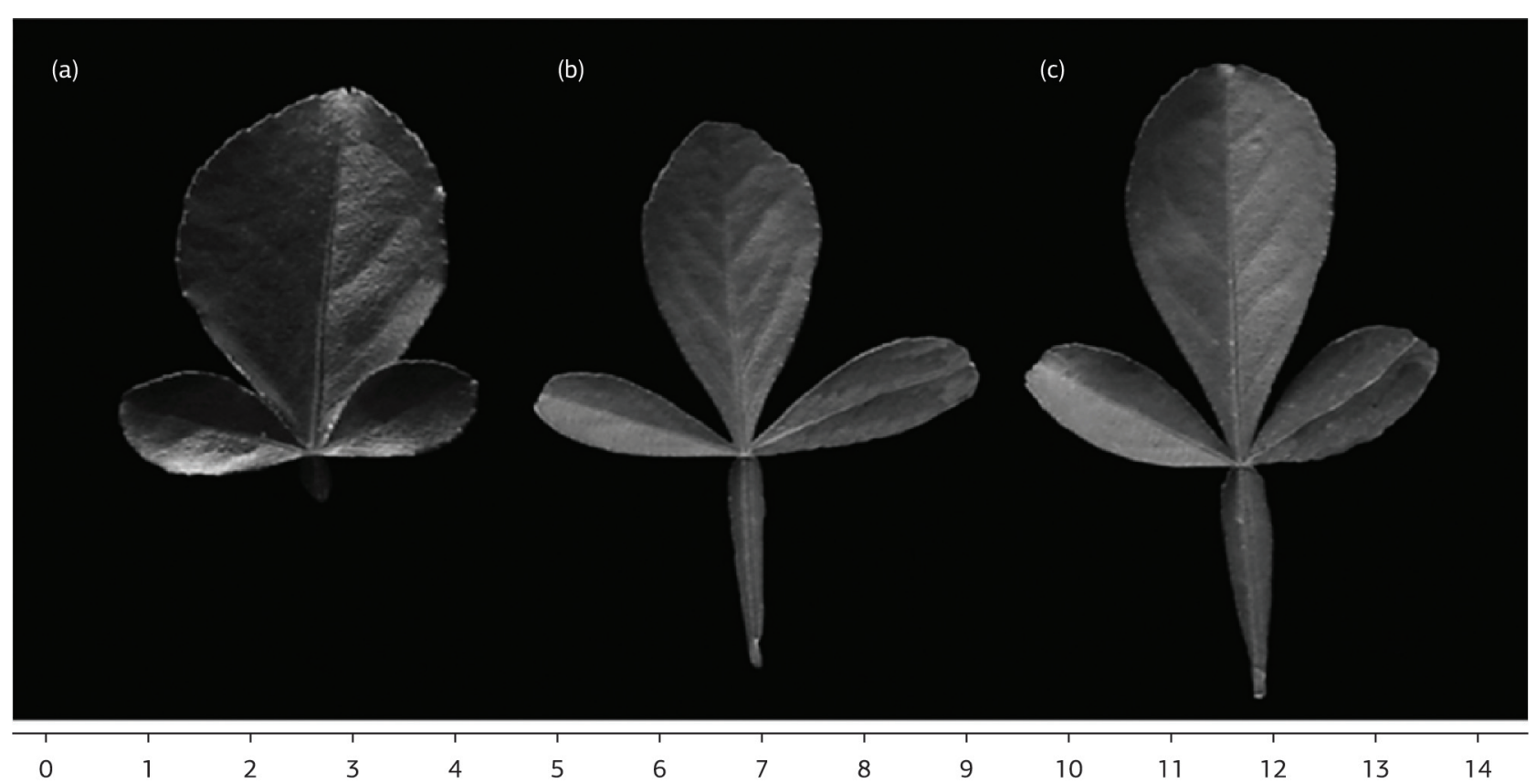

Figure 2. Morphological characterization of the leaves. (a) Leaf of the tetraploid plant rootstock Citrange 'Fepagro C13'. (b) and (c) Leaves of the diploid plant rootstock citrange 'Fepagro C13'. Scale Bar $=\mathrm{cm}$.

width of the leaf (Table 3). The highest values of petiole length were found in the diploid plants (Table 3), with the longest petiole length in diploid plants being $1.45 \mathrm{~cm}$ in the 'Fepagro C13' rootstock, while $0.85 \mathrm{~cm}$ in the tetraploid. The longest petiole length in diploid plants was found in the 'Fepagro C37' with $2.37 \mathrm{~cm}$, whereas it was $1.23 \mathrm{~cm}$ in the tetraploid rootstock (Table 3).

In the overall average of rootstocks, there were significant statistical differences and the diploid plants presented longer petioles, averaging $1.78 \mathrm{~cm}$, while the tetraploids presented an average of $0.99 \mathrm{~cm}$ (Table 3). These results are consistent with those proposed by Frost and Soost (1968), that the diploid plants present longer petioles than the polyploids.

When analyzing the length of the leaves, in most evaluations the leaves of the diploid individuals were shorter than those of the tetraploids. In diploid plants, the lowest average length was $2.18 \mathrm{~cm}$ in 'Troyer', while the tetraploid presented $2.84 \mathrm{~cm}$ and the greatest leaf was
$2.56 \mathrm{~cm}$ in 'Fepagro C13', while the tetraploid presented $3.18 \mathrm{~cm}$ (Table 3 and Figure 2).

In the overall average there were significant statistical differences between diploids and tetraploids, where the tetraploid plants had a longer leaf length with a mean of $2.95 \mathrm{~cm}$ and the diploids a mean of $2.32 \mathrm{~cm}$ (Table 3).

Regarding the width of the blade of the central leaflet of the leaves, diploid plants showed smaller width than the tetraploids (Table 3). In the overall average the tetraploid plants presented a central leaflet blade with a width of 1.69 $\mathrm{cm}$ and the diploids $1.33 \mathrm{~cm}$ (Figure 2), but in average there was no significant statistical difference between diploid and tetraploid plants, even if the tetraploid presented a tendency for leaves with a width greater than the diploids.

The largest length and width of leaves observed in tetraploid plants in this study (Table 3 and Figure 2) agree with what has been described by Latado et al. (2007), who observed a greater width and thickness in leaf blades of polyploidy citrus plants compared with diploids, and also 
Table 3. Comparison between diploid and tetraploid plants of citrus rootstocks on the petiole length and length and width of the leaf

\begin{tabular}{ccccccc} 
Rootstock & \multicolumn{2}{c}{ Petiole Length $(\mathbf{c m})$} & \multicolumn{2}{c}{ Leaf Length $(\mathbf{c m})$} & \multicolumn{2}{c}{ Leaf Width (cm) } \\
& Plant $\mathbf{2 X}$ & Plant $\mathbf{4 X}$ & Plant 2X & Plant 4X & Plant 2X & Plant 4X \\
\hline 'Swingle' & $2.02 \mathrm{a}$ & $1.39 \mathrm{~b}$ & $2.49 \mathrm{~b}$ & $3.08 \mathrm{a}$ & $1.39 \mathrm{~b}$ & $1.89 \mathrm{a}$ \\
\hline 'Troyer' & $1.62 \mathrm{a}$ & $1.10 \mathrm{~b}$ & $2.18 \mathrm{~b}$ & $2.84 \mathrm{a}$ & $1.21 \mathrm{~b}$ & $1.66 \mathrm{a}$ \\
\hline 'Fepagro C 13' & $1.45 \mathrm{a}$ & $0.85 \mathrm{~b}$ & $2.56 \mathrm{~b}$ & $3.18 \mathrm{a}$ & $1.53 \mathrm{a}$ & $1.86 \mathrm{a}$ \\
'Fepagro C 37' & $2.37 \mathrm{a}$ & $1.23 \mathrm{~b}$ & $2.27 \mathrm{~b}$ & $2.82 \mathrm{a}$ & $1.33 \mathrm{a}$ & $1.66 \mathrm{a}$ \\
\hline Mean & $1.78 \mathrm{a}$ & $0.99 \mathrm{~b}$ & $2.32 \mathrm{~b}$ & $2.95 \mathrm{a}$ & $1.33 \mathrm{a}$ & $1.69 \mathrm{a}$ \\
\hline
\end{tabular}

Means followed by the same letter in the row in the comparison between diploid and tetraploid rootstocks did not differ significantly from the test Tukey ( $p>0.01$ )

- Swingle $2 X$

O Swingle $4 X$

$y=39,05 /(1+\operatorname{EXP}(-(x-41,21) / 78,91)), R^{2}=0,9906^{* * *}$

$--y=27,65 /(1+\operatorname{EXP}(-(x-64,21) / 78,66)), R^{2}=0,9926^{* * *}$
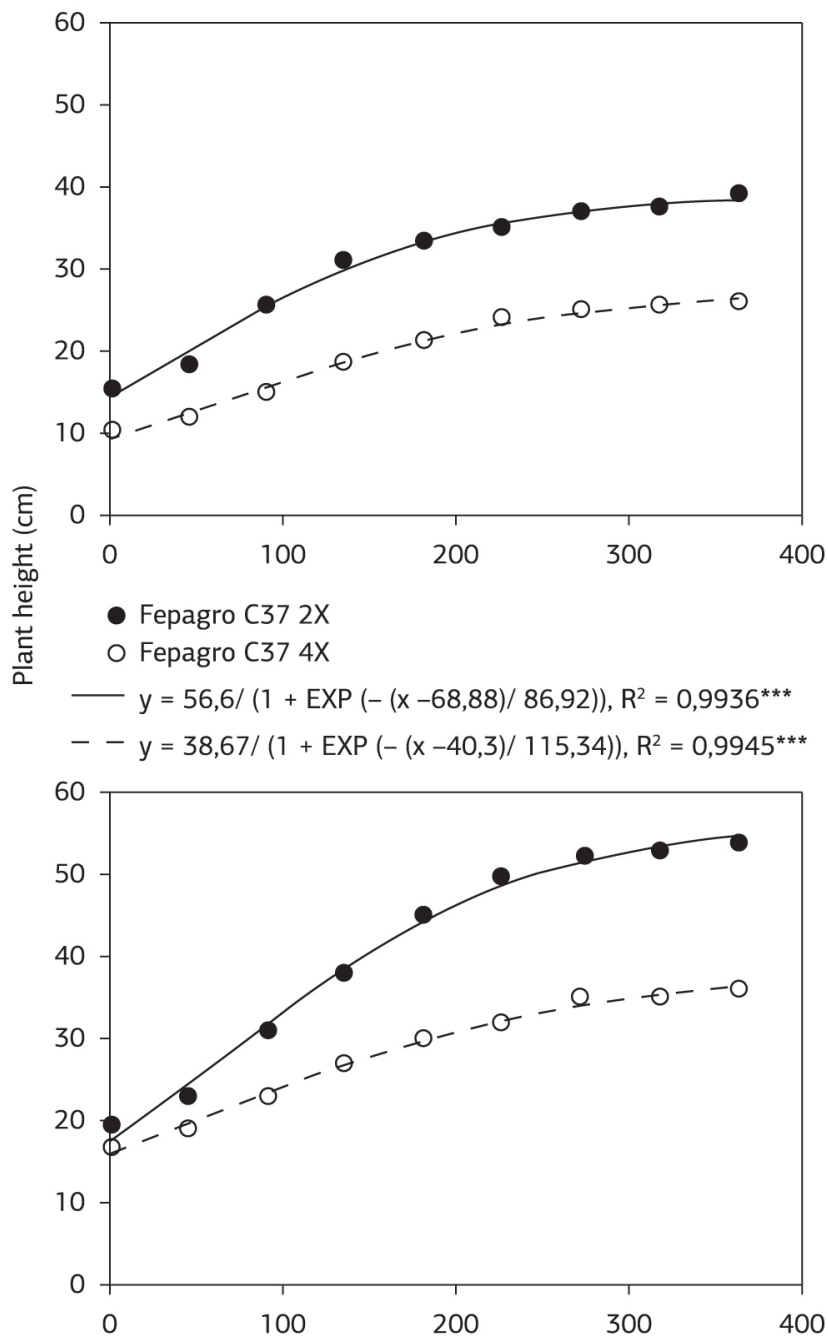

- Troyer $2 \mathrm{X}$

O Troyer $4 \mathrm{X}$

$-y=47,52 /(1+\operatorname{EXP}(-(x-25,99) / 105,24)), R^{2}=0,9905^{* *}$

$--y=37,48 /(1+\operatorname{EXP}(-(x-7,46) / 148,8)), R^{2}=0,9899^{* *}$

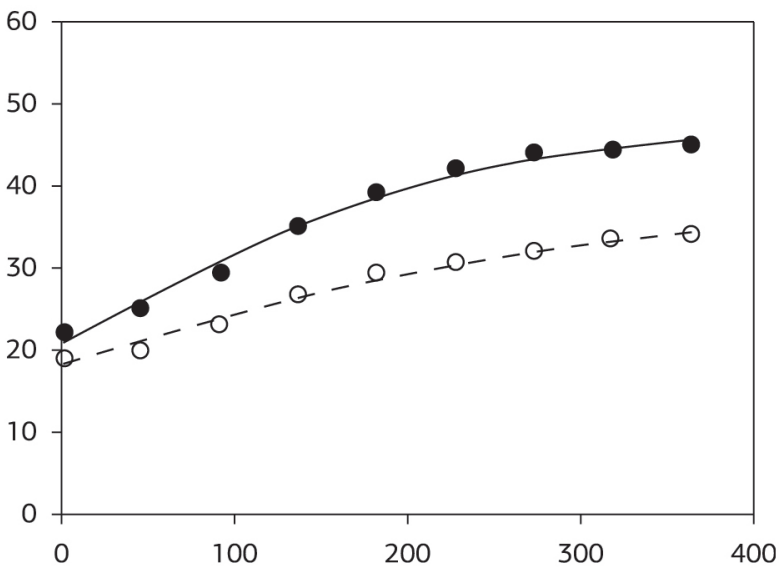

- Fepagro C37 2X

O Fepagro C37 4X

$-y=41,92 /(1+\operatorname{EXP}(-(x-62,23) / 67,96)), R^{2}=0,9989^{* * *}$

$--y=30,7 /(1+\operatorname{EXP}(-(x-49,85) / 80,16)), R^{2}=0,9970^{* * *}$

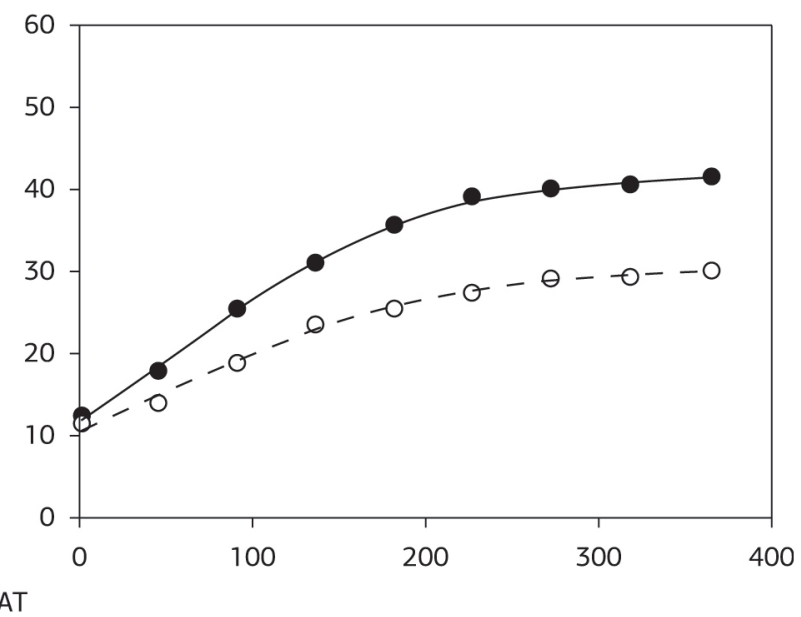

Figure 3. Plant height between diploid and tetraploid plants rootstocks 'Swingle', 'Troyer', 'Fepagro C13' and 'Fepagro C37'conducted side by side at greenhouse in the eight evaluation dates. DAT $=$ Days after transplantation; ${ }^{* * *}=$ significant regression, $\mathrm{P}<0.0001$.

with what was reported by Frost and Soost, (1968) and Machado et al. (2005) that the tetraploid citrus plants have larger, thicker and wider leaves than the leaves of diploid plants, characters possibly associated to fewer, but larger stomata (Syvertsen et al., 2000).
The growth evaluations found variations in plant height between diploid and tetraploid plants, and the diploids were always higher.

The greatest initial height in diploid plants was found in the 'Troyer' rootstock, with $22.2 \mathrm{~cm}$ in the first evaluation 
and $45.0 \mathrm{~cm}$ in the second one, while the tetraploid plant presented $19.2 \mathrm{~cm}$ and $34.0 \mathrm{~cm}$, respectively (Figure 3).

The lowest initial height in diploid plants was $12.4 \mathrm{~cm}$ in the 'Fepagro C37' rootstock in the first evaluation and $41.5 \mathrm{~cm}$ in the last, while in tetraploids the height was $11.2 \mathrm{~cm}$ and $30.0 \mathrm{~cm}$, respectively (Figure 3 ).

In this study, the results obtained with the height evaluations of diploid and tetraploid citrus plants over a year, allowed the observation that tetraploids presented a smaller and more compact form (Figure 3), agreeing with Cameron and Frost (1968) and Lee (1988), that morphological characteristics that are different among plants with different levels of ploidy, while polyploid plants have a more compact form and reduced size when compared to diploid plants. The results of this study are also consistent with data obtained by Allario et al. (2011) who compared the height between diploid and tetraploid plants derived from the same seed, the fruit of 'Rangpur' lime (C. limonia Osbeck) and observed that polyploid seedlings were smaller.

Frost and Soost (1968) highlighted that, regarding cytogenetics, the only variation between citrus autotetraploid plants and their diploid siblings is the duplicated number of chromosomes. However, according to these authors, regarding morphological and growth characters, the difference between diploid and tetraploids can easily be verified, since the tetraploid plants present slower growth, compacter shape, fewer and less vigorous sprouting. According to Syvertsen et al. (2000), the lowest growth rates observed in citrus seedlings from by tetraploid rootstocks are associated to the reduced rates of transpiration due to the lower number of stomata. Therefore, the lower growth and the more compact shape of the tetraploid plants observed in this study (Figure 3) agree with the affirmation of Frost and Soost (1968) that the distinction between diploids and tetraploids can be easily verified by analyzing morphological characters.

Citrus rootstocks should confer good characteristics to cultivate canopy, such as tolerance to drought and salinity, good quality and productivity of fruit (Allario et al., 2011; Hussain et al., 2012; Saleh et al., 2008), besides inducing reduction of the plant size (Pompeu Junior and Blumer, 2009), therefore facilitating orchard management. In this study, differences in morphological characteristics between diploid and tetraploid plants were observed, such as differences in growth, whereas tetraploid plants were always smaller and more compact.

\section{CONCLUSION}

Tetraploid plants present petioles smaller in length, but leaves larger in length and width;

Tetraploid plants are more compact and present smaller growth than diploids.

\section{ACKNOWLEDGEMENTS}

To CAPES (Coordenação de Aperfeiçoamento de Pessoal de Nível Superior, Brazil) and CNPq (Conselho Nacional de Desenvolvimento Científico e Tecnológico, Brazil) for finnancial support.

\section{REFERENCES}

ALEZA, P.; JUÁREZ, J.; OLLITRAULT, P.; NAVARRO L. Production of tetraploid plants of non apomictic citrus genotypes. Plant Cell Reports, v.28, p.1837-1846, 2009. PMid:19834711. http://dx.doi. org/10.1007/s00299-009-0783-2

ALEZA, P.; FROELICHER, Y.; SCHWARZ, S.; AGUSTI, M.; HERNÁNDEZ, M.; JUÁREZ, J.; LURO, F.; MORILLON, R.; NAVARRO, L.; OLLITRAULT, P. Tetraploidization events by chromosome doubling of nucellar cells are frequent in apomictic citrus and are dependent on genotype and environment. Annals of Botany, v.108, p.37-50, 2011. PMid:21586529 PMCid:PMC3119611. http:// dx.doi.org/10.1093/aob/mcr099

ALLARIO, T.; BRUMOS, J.; COLMENERO-FLORES, J.M.; TADEO, F.; FROELICHER, Y.; TALON, M.; NAVARRO, L.; OLLITRAULT, P.; MORILLON, R. Large changes in anatomy and physiology between diploid Rangpur lime (Citrus limonia) and its autotetraploid are not associated with large changes in leaf gene expression. Journal of Experimental Botany, v.62, p.2507-2519, 2011. PMid:21273338. http://dx.doi.org/10.1093/jxb/erq467

CAMERON, J.W.; FROST, H.B. Genetics, breeding, and nucellar embryony. In: THE CITRUS Industry. Berkeley: University of California, 1968. p.325-370.

CHAGAS, E.A.; CAZETTA, J.O.; LEMOS, E.G.M.; PASQUAL, M.; GOES, A.; RAMOS, J.D.; PIO, R.; BARBOSA, W.; MENDONÇA, V.; AMBROSIO, L.A. Identificação de híbridos de citros resistentes à mancha-marrom-de-alternária por meio de AFLP e testes de patogenicidade. Pesquisa Agropecuária Brasileira, v.42, p.975-983, 2007. http://dx.doi.org/10.1590/S0100-204X2007000700009

DAHMER, N.; SCHIFINO-WITTMANN, M.T.; GUERRA, D.; WEILER, R.L. Bracatinga (Mimosa scabrella Bentham), a multipurpose tree growing in Southern Brazil: chromosome number and genetic variation. Genetic Resources and Crop Evolution, v.60, p.377-383, 2013. http://dx.doi.org/10.1007/s10722-012-9931-6

DAVIES, F.S.; ALBRIGO, L.G. Citrus. Wallingford: CABI, 1994. $254 \mathrm{p}$.

FROST, H.B.; SOOST, R.K. Seed reproduction: Development of gametes and embryos. In: REUTHER, W.; BATCHELOR, L.D.; WEBBER, H.J. (Eds.). The citrus industry II. Berkeley: California Univ. Press, 1968. p.290-324.

GONZATTO, M.P.; KOVALESKI, A.P.; BRUGNARA, E.C.; WEILER, R.L.; SARTORI, I.A.; LIMA, J.G.; BENDER, R.J.; SCHWARZ, S.F. Performance of 'Oneco' mandarin on six rootstocks in South Brazil. Pesquisa Agropecuária Brasileira, v.46, p.406-411, 2011. http://dx.doi. org/10.1590/S0100-204X2011000400010

GUERRA, D.; SCHIFINO-WITTMANN, M.T.; SCHWARZ, S.F.; SOUZA, P.V.; WEILER, R.L. Caracterização morfológica, 
determinação do número de embrióes e taxa de poliembrionia em três porta-enxertos híbridos de citros. Bragantia, v.71, p.196-201, 2012. http://dx.doi.org/10.1590/S0006-87052012000200007

HUSSAIN, S.; CURK, F.; DHUIQUE-MAYER, C.; URBAN, L.; OLLITRAULT, P.; LURO, F.; MORILLON, F. Autotetraploid trifoliate orange (Poncirus trifoliata) rootstocks do not impact clementine quality but reduce fruit yields and highly modify rootstock/scion physiology. ScientiaHorticulturae, v.134, p.100-107, 2012. http:// dx.doi.org/10.1016/j.scienta.2011.11.008

INTERNATIONAL BOARD FOR PLANT GENETIC RESOURCES - IBPGR. Descriptors for Citrus. Rome: IBPGR, 1988. 27p.

LATADO, R.R.; CRISTOFANI-YALY, M.; CARVALHO, C.R.; MACHADO, M. A. Plantas autotetraploides de citros sob tratamento in vitro com colchicina. Pesquisa Agropecuária Brasileira, v.42, p.14291435, 2007. http://dx.doi.org/10.1590/S0100-204X2007001000009

LEE, L.S. Citrus polyploidy - origins and potential for cultivar improvement. Australian Journal of Agricultural Research, v.39, p.735-747, 1988. http://dx.doi.org/10.1071/AR9880735

LEECHET, R.M.; LEESE, B.M.; JELLINGS, A.J. Variation in cellular ribulose-1, 5-bisphospahte-carboxylase content in leaves of Triticum genotypes at tree levels of ploidy. Planta, v.166, p.259-263, 1985. PMid:24241441. http://dx.doi.org/10.1007/BF00397357

MACHADO, M.A.; CRISTOFANI-YALY, M.; AMARAL, A.M.; OLIVEIRA, A.C. Genética, melhoramento e biotecnologia de citros, In: MATTOS JUNIOR, D.; DE NEGRE, J.D.; PIO, R.M.; POMPEU JUNIOR, J. (Eds.). Citros. Campinas: Instituto Agronômico, 2005. p.221-277.

MOREIRA, R.A.; RAMOS, J.D.; CRUZ, M.C.M. Caracterização de frutos e poliembrionia em sementes de 'Flying Dragon' e de híbridos de porta-enxerto de citros. Revista Brasileira de Fruticultura, v.32, p.486492, 2010. http://dx.doi.org/10.1590/S0100-29452010005000056

MURASHIGE, T.; SKOOG, F. A revised medium for rapid grow than bioassays with tobacco cultures. Physiology Plant, v.15, p.473497, 1962. http://dx.doi.org/10.1111/j.1399-3054.1962.tb08052.x
OLLITRAULT, P.; JACQUEMOND, C. Facultative apomixis, spontaneous polyploidization and inbreeding in Citrus volkameriana seedlings. Fruits, v.49, p.479-480, 1994.

PASSOS, O.S.; PEIXOUTO, L.S.; SANTOS, L.C.; CORREAA, R.C.; SOARES FILHO, W.S. Caracterização de híbridos de Poncirus trifoliata e de outros porta-enxertos de citros no Estado da Bahia. Revista Brasileira de Fruticultura, v.28, p.410-413, 2006. http:// dx.doi.org/10.1590/S0100-29452006000300016

POMPEU JUNIOR, J.; BLUMER, S. Híbridos de Trifoliata como porta-enxertos para a laranjeira Valência. Pesquisa Agropecuária Brasileira, v.44, p.701-705, 2009. http://dx.doi.org/10.1590/S0100204X2009000700008

POMPEU JUNIOR, J. Porta-enxertos. In: CITROS. Campinas: Instituto Agronômico, 2005. v.1, p.61-104.

SALEH, B.; ALLARIO, T.; DAMBIER, D.; OLLITRAULT, P.; MORILLON, R. Tetraploid citrus rootstocks are more tolerant to salt stress than diploid. Compets Rendus Biologies, v.331, p.703-710, 2008. PMid:18722990. http://dx.doi.org/10.1016/j.crvi.2008.06.007

SAUNT, J. Citrus varieties of the would: and illustrated guide. Norwick: Sinclair International, 1990. 128p.

SCHÄFER, G.; DORNELLES, A.L.C. Produção de mudas cítricas no Rio Grande do Sul - Diagnóstico da região produtora. Ciência Rural, v.30, p.587-592, 2000. http://dx.doi.org/10.1590/S010384782000000400005

STATISTICAL ANALISYS SYSTEM INSTITUTE - SAS. SAS OlineDoc. version 8.02. 2000. Disponível em: <http://v8dos.sas. $\mathrm{com} / \mathrm{sashtml} />$.

SYVERTSEN, J.P.; LEE, L.S.; GROSSER, J.W. Limitations on growth and net gas exchange of diploid and tetraploid Citrus rootstock cultivars grown at elevated $\mathrm{CO}_{2}$. Journal of the American Society for Horticultural Science, v.125, p.228-234, 2000. 